\title{
Are there Long-Term Earnings Scars from Youth Unemployment in Germany?
}

\author{
Joachim Möller* \\ Institute for Employment Research (IAB), Nuremberg, University of Regensburg, \\ and Institute for the Study of Labor, Bonn
}

\section{Matthias Umkehrer \\ Institute for Employment Research (IAB), Nuremberg}

JEL J30; J69; C21; C26

Scarring; state dependence; youth unemployment.

\section{Summary}

We analyze the relationship between early-career unemployment and prime-age earnings with German administrative linked employer-employee data. The careers of more than 720,000 male apprenticeship graduates from the cohorts of 1978 to 1980 are followed over 24 years. On average, early-career unemployment has substantial negative effects on earnings accumulated later in life. An identification strategy based on plant closure of the training firm at the time of graduation suggests that the revealed correlation is not the result of unobserved heterogeneity. Scarring effects also vary considerably across the earnings distribution. Workers with a high earning potential are able to offset adverse consequences of early-career unemployment to a large extent. Workers who are located at the bottom of the prime-age earnings distribution, in contrast, suffer substantial and persistent losses. Our findings imply that a policy with the aim of preventing early-career unemployment would have long-lasting beneficial effects on future earnings.

\section{Introduction}

Young workers are generally more susceptible to become unemployed than experienced workers, cf. Farber (1993). At the OECD average, the unemployment rate among the 15 to 24 year old is about twice the general rate (Table 1). Moreover, unemployment rates have reached a worryingly high level in the aftermath of the great recession, particularly among youth. This is the case in most European countries and in the U.S. In Germany, in contrast, unemployment has declined between the years 2006 and 2012. Youth unemployment is only about half the OECD rate and the ratio of youth unemployment to total unemployment is lower than in other countries. However, also here youth unemployment is elevated and the ratio slightly increased since 2006 .

The relatively favorable situation in the German case is related to at least three factors. First, youth unemployment responds sensitively to a general under-utilization of the labor force in times of economic crisis. Compared to other countries, Germany has been able

* We would like to thank Stefan Bender, Philipp vom Berge, Steffen Müller, Achim Schmillen, the referees, and the participants of the ZEW workshop on youth unemployment for valuable comments. The usual disclaimer applies. 
to surmount the dramatic demand shock of the Great Recession in a surprisingly short time and experienced a substantial employment increase in the aftermath of the crisis, see Möller (2010). Second, the German system of vocational training is successful in preparing young workers for their further professional life. And last but not least, youth unemployment was always of great concern in German active labor market policy. The emphasis laid on the labor market situation of young workers is also the merit of leading labor economists like Wolfgang Franz, who scrutinized not only the particularities of the labor market situation for young workers, but also warned against the severe long-run consequences of joblessness at the beginning of a professional career, cf. Franz (1981); Franz et al. (1997); Franz and Zimmermann (2002).

Table 1 Aggregate Unemployment Rate (in percent)

\begin{tabular}{lrrrrrrr}
\hline & OECD & Germany & U.S. & France & Italy & Greece & Spain \\
\hline 2006 & & & & & & & \\
aged 15-24 & 12.5 & 13.8 & 10.5 & 21.7 & 21.6 & 25.2 & 17.9 \\
all persons & 6.1 & 10.3 & 4.6 & 8.8 & 6.8 & 8.9 & 8.5 \\
ratio & 2.1 & 1.3 & 2.3 & 2.5 & 3.2 & 2.8 & 2.1 \\
2012 & & & & & & & \\
aged 15-24 & 16.2 & 8.2 & 16.2 & 23.8 & 35.2 & 55.3 & 53.2 \\
all persons & 7.9 & 5.5 & 8.1 & 9.9 & 10.7 & 24.2 & 25.0 \\
ratio & 2.0 & 1.5 & 2.0 & 2.4 & 3.3 & 2.3 & 2.1 \\
\hline
\end{tabular}

Source: OECD (2014)

Our article stands in this tradition. Starting from the fact that young workers' wages are also particularly vulnerable to adverse economic shocks, see Blanchflower and Oswald (1994), we ask whether unemployment experienced at an early stage of the career reduces total earnings accumulated during an established part of the professional history.

As is outlined by Heckman and Borjas (1980), a structural link between (youth) unemployment and later labor market outcomes may exist if, for instance, individuals loose productivity-enhancing work experience during unemployment periods, or if prospective employers refer information about an individual's productivity from unemployment records when making hiring and investment decisions. Alternatively, young workers might be able to offset adverse consequences of unemployment during the course of the early career, which is generally characterized by a high degree of job mobility and rapid wage growth, cf. Topel and Ward (1992). Consequently, it remains an empirical question whether or not youth unemployment involves longer-term earnings losses. If future earnings truly depend on the state of unemployment during the early career this would call for policy measures aiming at the prevention of youth unemployment in order to avoid future earnings loss.

Our empirical strategy focuses on German males who graduated from Germany's dual apprenticeship system between the years 1978 and 1980. This relatively homogenous and quantitatively important group enters the German labor market under similar economic conditions. ${ }^{1}$ What makes it an interesting case to study is that it experiences the severe recession in the aftermath of the second oil price shock at the beginning of professional life.

1 Around 60 percent of a cohort enter the German labor market through the dual apprenticeship system. This system combines apprenticeship training with a company and vocational education at school, see Hippach-Schneider et al. (2007) for a detailed description. 
Our administrative data set, the Integrated Employment Biographies (IEB), described by Oberschachtsiek et al. (2009) and provided by the Institute for Employment Research (IAB) in Nuremberg, Germany, allows us to observe the complete employment biographies of all of these individuals starting with their first day of training. Following Schmillen and Umkehrer (2013), we define the early career as the period between the end of apprenticeship training and the end of the eighth year that has passed since graduation. The subsequent 16 years of potential experience are defined as prime age. ${ }^{2}$ We aim at investigating whether unemployment experienced during early career has negative effects on the distribution of earnings from employment subject to social security contributions accumulated during prime age.

Ordinary least squares (OLS) estimates, controlling for initial sorting into training firms by including training firm fixed effects, show an effect of early-career unemployment which is both statistically and economically significant: The estimated semi-elasticity of prime-age earnings with respect to early-career unemployment, evaluated at one standard deviation of early-career unemployment (326 days), is -24.9 percent. Other things being equal, this estimate would imply that experiencing joblessness for about one year during the first eight years in the labor market reduces average earnings in the following 16 years by roughly one quarter.

To solve the potential problem of adverse selection and voluntary mobility, outlined in detail by von Wachter and Bender (2006), we use plant closure of the training firm occurring in the year of graduation as an instrument for early-career unemployment. With respect to random assignment of the instrument, Hamermesh (1987) demonstrates that a plant closure is hardly predictable by the workers who are affected. This view is supported by Ruhm (1991) or Dustmann and Meghir (2005), who show that wage changes induced by plant closures do not become visible earlier than two calendar years in advance. Consequently, after having controlled for sorting between training firms, we should be able to assure ignorable assignment of the instrument by focusing on those apprentices who have spent at least two years of training with the firm before it closes down. ${ }^{3}$

We further assume that the exclusion restriction holds because, in the presence of changing economic conditions, human capital accumulation, and early-career matching processes, the disruption in the employment process is most likely to be the only persistent link between an exogenous and transitory labor demand shock at the transition from training to work and the level of earnings after at least nine years of potential experience. ${ }^{4}$ The instrumental variable (IV) estimates suggest that our OLS estimates of the scarring effect of early-career unemployment on prime-age earnings are not substantially biased upwards. Furthermore, when we allow the effects of early-career unemployment to vary across the unconditional distribution of prime-age earnings, we find that the impact of early-

2 The reason behind this cut-off of the early career and prime age is that the first years in the labor market are subject to an adjustment process, characterized by high job mobility and temporarily elevated unemployment. Judging from Appendix 8.3 of Schmillen and Umkehrer (2013), this adjustment process lasts approximately eight years.

3 Sorting between training firms based on the likelihood of a plant closure turns out to be an important confounding factor. Since a person's later mobility might already be influenced by early-career unemployment, among other things, controlling for sorting becomes a considerably more complex task once workers have entered the labor market. For this reason, we focus on plant closure of the training firm occurring in the year of graduation.

4 Since exclusion of initial plant closure from the second stage regression is a critical assumption, we will address it in detail in Section 5.2.2. 
career unemployment is highly heterogeneous: The effects on the first decile are more than ten times larger than the effects on the ninth decile. This pattern suggests that workers with a high earning potential have characteristics which allow them to offset the adverse consequences of early-career unemployment to a certain extent. By contrast, workers with a low earning potential suffer substantial earnings losses from early-career unemployment.

Our study is associated with the broad literature on state dependence between past unemployment experiences and future labor market outcomes. Previous studies for the labor market in the U.S. give little evidence for the assertion that past unemployment causes future unemployment, cf. Heckman and Borjas (1980); Corcoran and Hill (1985). The German literature reveals stronger scarring effects of this type in general settings, cf. Mühleisen and Zimmermann (1994); Biewen and Steffes (2010); Niedergesäss (2012). Particularly youth unemployment is frequently found to entail permanent employment and/or wage losses. In the U.S., the impact of youth unemployment appears to be mainly on future wages, cf. Ellwood (1982); Mroz and Savage (2006). The European literature, in contrast, reports both negative wage and employment effects, cf. Nilsen and Reiso (2011); Nordström Skans (2011) for Norway, Arulampalam et al. (2000); Arulampalam (2001); Gregg (2001); Gregg and Tominey (2005) for Great Britain, or Ryan (2001) for a cross-national comparison. For Germany, there is still comparatively little research on long-term consequences of youth unemployment. One exception is the study by Franz et al. (1997), who provide evidence that dropping out of apprenticeship training can permanently reduce subsequent earnings. To contribute to the existing literature, we extend the study by Schmillen and Umkehrer (2013) by analyzing the earnings effects of early-career unemployment from a long-term perspective. The latter study finds that, in Germany, early-career unemployment leads to more unemployment later in life.

The article proceeds as follows: The next two sections introduce our data set and describe our key variables. Section 4 outlines conceptual considerations, while Section 5 presents and interprets the regression results. Finally, Section 6 concludes.

\section{Data and variables}

Our empirical analysis focuses on all male German workers who graduated from the dual apprenticeship system in Western Germany. We study this particular group of workers because, on the one hand, its members are comparatively homogenous concerning background, training, and career prospects. Still, apprenticeship graduates are quantitatively the most important group in the German labor market. On the other hand, our administrative data set, the Integrated Employment Biographies (IEB), described by Oberschachtsiek et al. (2009), of the Institute for Employment Research (IAB) in Nuremberg, Germany, provides us with detailed information on labor market states, such as apprenticeship training, employment subject to social security contributions, and unemployment benefit receipt. The inclusion of training spells enables us to identify the exact time and place of labor market entry for apprentices.

The IEB further contain details on wages and a variety of socio-demographic characteristics. Information on the employer side is added by merging the IEB with the Establishment History Panel (BHP), see Hethey-Maier and Seth (2010). The BHP encompasses all German establishments with at least one worker employed subject to social security contributions on June $30^{\text {th }}$ of any given year. Because both data sets are based on process 
generated data, which is used by Germany's social security agencies to compute social security contributions and unemployment benefits, they are highly reliable.

To enable a long-term perspective on detailed labor market biographies, we restrict our sample to the cohorts from the years 1978, 1979, and 1980. Cohort membership is determined by the calendar year in which an apprentice graduates, and graduation is defined as the last day of the first apprenticeship period recorded in the data. We further exclude all individuals who are younger than 15 , or older than 26, when graduating. Around 5 percent of all selected individuals hold a high school diploma at the time of graduation. We also exclude them from the analyses.

728,841 individuals remain in the final sample. We follow their professional careers over the first 24 years since graduation and define the first eight years as early career and the last 16 years as prime age. As in Schmillen and Umkehrer (2013), we construct our key regressor - early-career unemployment - by adding up all the days an individual was registered as unemployed during the early career. Since apprentices in the dual system pay contributions to unemployment insurance, they are eligible to receive unemployment benefits after a qualifying period of one year of training. However, before the year 2000, the IEB do not contain information on individuals who are officially registered as jobseeking at the German Federal Employment Agency. This is why we consider a worker as unemployed if he receives any unemployment benefit payments.

The dependent variable - prime-age earnings - is constructed by multiplying the duration of each employment spell in prime age with its corresponding daily gross wage, deflated to 2005 Euro using the CPI provided by Germany's Federal Reserve, see Deutsche Bundesbank (2012). Any type of covered employment is considered. In case of parallel spells, we include only the one with the highest wage. However, wages in the IEB are top-coded if they exceed the upper earnings limit for statutory pension insurance. In these cases, we use Tobit models to impute hypothetical uncensored wages. The final measure is the sum of these spell earnings.

We also observe a rich set of characteristics related to the individual and the establishments from which we construct several control variables. Usually, we extract this information from the graduation spell to avoid problems that may arise if the control variables are determined by the key regressor. These controls comprise: the labor market entry cohort, the age at graduation, the daily remuneration, the training occupation as well as the sector, size, and the median wage of the training firm. To capture differences in local labor demand at the transition from early career to prime age, we follow Gregg (2001) and use county-specific unemployment rates prevailing in the district of the last pre-transition employment spell. ${ }^{5}$

\section{Descriptives}

Table 2 gives some descriptive information on the data. The median early-career unemployment is 15 calendar days, i.e. the majority of young workers did not suffer from substantial unemployment in the first eight years of their professional life. On average, members of the group of workers with at least 15 days of early-career unemployment earn about 535 thousand Euro during their prime age employment period, with a standard

5 See Table A1 in the Appendix for summary statistics. Further details on data selection and construction of the control variables can be found in Appendix 8.1 of Schmillen and Umkehrer (2013). 
deviation of almost 275 thousand. In the higher percentile ranges of the early-career unemployment distribution, mean prime-age earnings follow a monotonic substantial decline. Those who are in the range between the eighth and the ninth decile, - i.e. were unemployed for 326 to 603 days during their early career - had mean cumulative earnings in their prime age period of about 346 thousand, with a standard deviation of 223 thousand. For the group above the 95 th percentile of early-career unemployment, mean cumulative earnings in the prime age period drop to less than 234 thousand Euro. This is only 44 percent of the mean earnings for those below the median, i.e. workers who have experienced no or almost no joblessness in their early working life. The standard deviation of cumulative prime-age earnings decreases in the higher percentile ranges, but by markedly less than the mean. Consequently, the coefficient of variation between workers below the median and those in the top group of early-career unemployment increases substantially. Figure 1 shows that early-career unemployment is highly concentrated. On the one hand, almost half of the workers in our sample did not experience a single day of joblessness in the first eight years of their working life. On the other hand, 10 percent of the workers with the highest incidence of unemployment during the early career were unemployed for twenty months or longer. ${ }^{6}$

Figure 2 depicts the cumulative density function for the sum of earnings in the prime age period. The graph reveals that there is substantial variation in earnings. In our sample, median cumulative prime-age earnings are roughly 0.5 million Euro. The first quartile of this earnings measure is about a quarter of a million, whereas the third quartile is more than 0.6 million Euro. 10 percent of persons in our sample have cumulative prime-age earnings exceeding three quarter of a million Euro. ${ }^{7}$

Table 2 Descriptive Statistics of Prime-Age Earnings by Percentile Range of Early-Career Unemployment

\begin{tabular}{lcrrrr}
\hline $\begin{array}{l}\text { percentile } \\
\text { range }\end{array}$ & $\begin{array}{c}\text { quantiles of } \\
\text { early-career unemp. } \\
\text { (in days) }\end{array}$ & $N$ & $\begin{array}{c}\text { mean } \\
\text { (in Euro) }\end{array}$ & $\begin{array}{c}\text { prime-age earnings } \\
\text { stand. dev. } \\
\text { (in Euro) }\end{array}$ & coef. of var. \\
\hline min-median & {$[0-15]$} & 365,168 & 535,757 & 274,427 & 0.51 \\
median-p60 & ] $15-77]$ & 72,485 & 471,015 & 261,419 & 0.56 \\
p60-p70 & ] $77-172]$ & 72,647 & 434,322 & 256,211 & 0.59 \\
p70-p80 & ] $172-326]$ & 72,808 & 386,763 & 236,212 & 0.61 \\
p80-p90 & ]326-603] & 72,955 & 345,864 & 223,360 & 0.65 \\
p90-p95 & ] $603-873]$ & 36,352 & 357,857 & 269,607 & 0.75 \\
p95-max & ]873-2,886] & 36,426 & 233,952 & 202,547 & 0.87 \\
\hline
\end{tabular}

Notes: Own calculations with IEB data.

\footnotetext{
6 This result was already shown by Schmillen and Umkehrer (2013), who also find that the distribution of unemployment accumulated in prime age is even more concentrated than the distribution of early-career unemployment.

7 Some of the numbers underlying Figure 1 and Figure 2 can be found in Table A2 of the Appendix.
} 


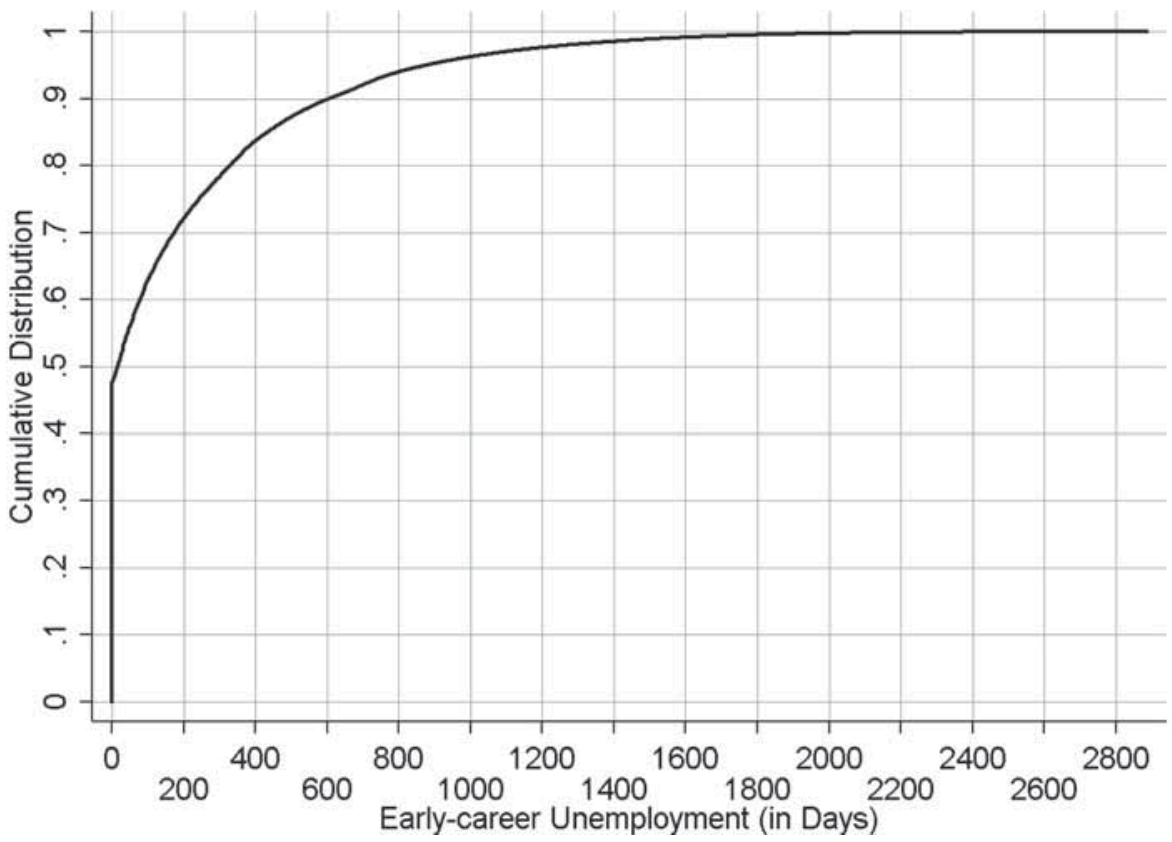

Figure 1 Empirical Cumulative Distribution Function of Early-Career Unemployment

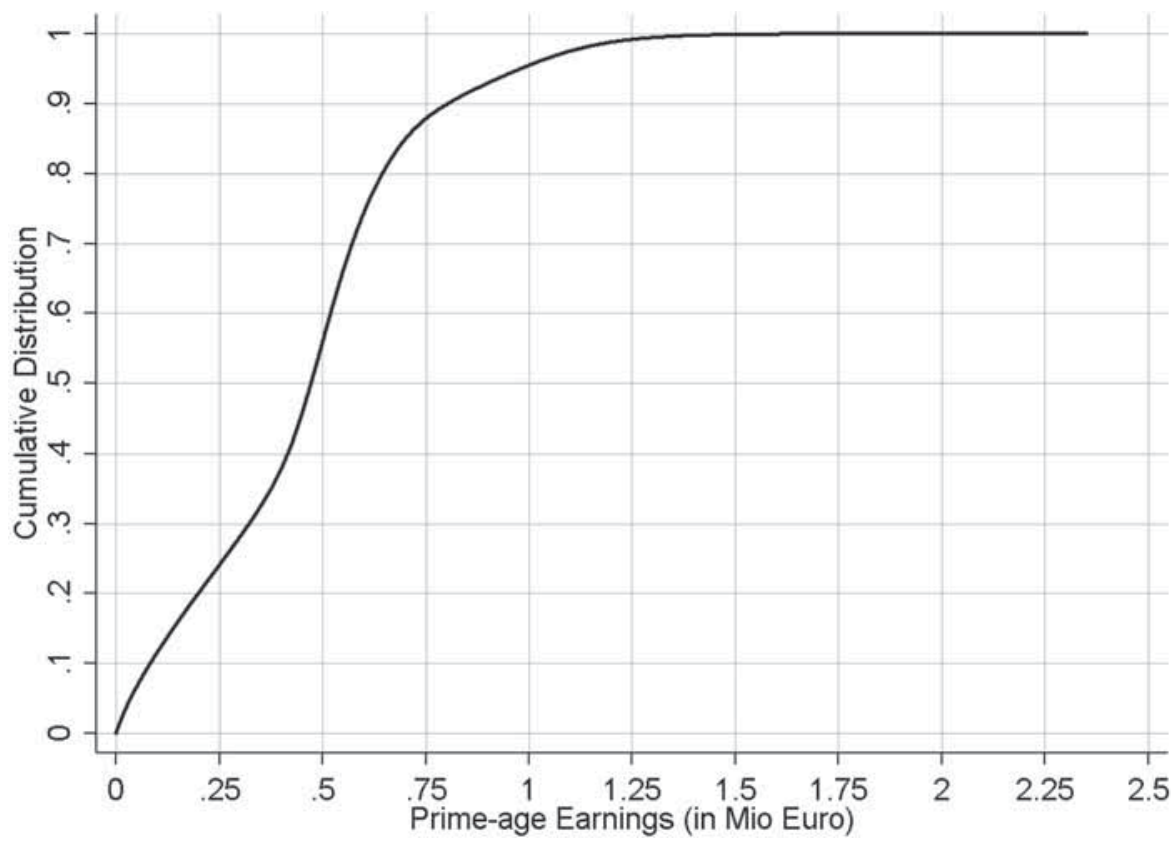

Figure 2 Empirical Cumulative Distribution Function of Prime-Age Earnings 


\section{Conceptual considerations}

\subsection{Possible confounding factors}

Insofar as early-career unemployment deteriorates existing human capital, prevents the young worker from the acquisition of productive skills and knowledge, or conveys a negative signal to the labor market, it has a true impact on future earnings. This would mean that the reduction or absence of unemployment early in professional life would imply an increase of earnings later on in a causal sense.

Identifying this causal link is not a trivial task. A regression of prime-age earnings on the duration of early-career unemployment is rather likely plagued with endogeneity of the explanatory variable. There are at least three reasons for this: First, apprentices might sort themselves, or might be sorted, into particular firms that offer different career opportunities or a different quality of training. For instance, if some workers graduate from firms that provide better career prospects than others, they will on average experience a smoother training to work transition and earn higher wages later in life, holding everything else constant.

The second and third reason are related to workers' mobility taking place during the course of the early career. ${ }^{8}$ The second mechanism that could generate endogeneity of early-career unemployment starts from the fact that firms may use the training period as a screening device. As a result, they dismiss their least successful graduates if they expect their costs to outweigh their productivity, cf. Franz and Zimmermann (2002). If such a non-prolongation of an employment contract after graduation is interpreted by potential alternative employers as a sign of low productivity, dismissed workers will have to face less stable jobs and lower wage offers in the future, cf. Spence (1973); Gibbons and Katz (1991).

Finally, the third mechanism is related to the possibility that graduates might leave the training firm voluntarily in order to form better matches with alternative employers. If some workers realize higher returns to search than others, they trade off potential wage gains from job stability during the early career against more stable and higher paying jobs later in life, cf. Neumark (2002). It is well documented that the early career is characterized by a high degree of job mobility in the U.S., cf. Topel and Ward (1992). For German apprentices, job shopping is an almost equally important source of wage growth, cf. Adda et al. (2013). Moreover, Franz (1981) finds a positive correlation between unemployment duration and initial education in his sample of German young people, which suggests that pronounced job search or further educational achievement involve temporary periods of unemployment.

Not appropriately controlling for one of the three mechanisms outlined above can result in biased estimates of the effect of early-career unemployment on prime-age earnings. Specifically, the presence of initial sorting of workers into highly productive firms and the negative selection of revealed under-performing workers out of firms would result in an upward bias. By contrast, the presence of voluntary mobility would induce a downward bias, see von Wachter and Bender (2006).

\footnotetext{
8 In our sample, only 19 percent of all apprentices stay with their training firm for the first eight
} years of their careers or longer. 


\subsection{Identification strategy}

Our empirical strategy to identify possible long-term earnings losses of early-career unemployment is to start with a simple OLS regression of prime-age earnings on early-career unemployment, and then to successively control for initial sorting, negative selection, and voluntary mobility. As long as selection between training firms is based on observables, like wage level and size of the training firm, including our control variables in the regressions solves the potential problem of sorting. Since it is very common for German apprentices to live near the firm in dedicated boarding houses during the period of training, we also control for fixed effects of the training firm's district. Ultimately, we replace district fixed effects with fixed effects at the level of the training firm to control for further invariant firm characteristics, which might be of relevance for the process of sorting but are not included in our data.

Although we have very detailed information on individual employment histories, explicitly modelling the processes of job shopping and negative selection appears rather difficult. The route we take here to separate spurious correlations from structural relationships is to instrument early-career unemployment with the event of a plant closure of the firm that provided training, occurring in the year of graduation. ${ }^{9}$ If, having controlled for initial sorting, the graduates involved in a plant closure are dismissed due to an unanticipated and exogenous establishment-specific labor demand shock, this group of leavers constitutes a random draw from the population. Therefore, applying this strategy should solve the potential problems of voluntary mobility and negative selection. Since a plant closure can hardly be anticipated earlier than two years in advance, see Hamermesh (1987); Ruhm (1991); and Dustmann and Meghir (2005), we focus on those graduates who have spent at least two years of training at the firm before the firm closes down. ${ }^{10}$

However, the IV strategy requires additional assumptions regarding the process of initial sorting and the mechanisms through which plant closures impact the level of earnings more than eight years later. Since there is virtually no within cohort-firm variation in plant closures, we cannot control for sorting using firm fixed effects. Therefore, we have to assume that selection into training firms is based on observable individual and firm characteristics, as well as on invariant unobservable characteristics of the firm's local labor market. ${ }^{11}$

The most critical assumption we require for the IV strategy to identify a local average treatment effect on the treated is excludability of initial plant closure from the regression of prime-age earnings. In other words, we have to assume that plant closures taking place at the time of graduation exhibit a permanent effect on earnings only via the unemployment experience they induce. The particular channels through which early-career unemployment ultimately translates into lower earnings can be manifold, such as negative signalling, human capital depreciation, and non-accumulation of work experience or tenure during

9 We identify plant closures in our data by relying on the classification of Hethey and Schmieder (2010), which is based on worker flows between all German establishments. Specifically, we regard a "small death", an "atomized death", and a "chunky death", according to their classification, as the result of a plant closure. However, our data set provides employer characteristics only at the establishment level. To follow the standard notation, we use the terms establishment, plant, and firm interchangeably.

${ }^{10}$ According to Paragraph 22 of Germany's Vocational Training Act of 1969, it is also very difficult to change firms during the course of an apprenticeship.

11 OLS estimates that control for district fixed effects are very similar to those that control for firm fixed effects. We are therefore confident that this assumption is satisfied. 
unemployment. ${ }^{12}$ To achieve identification, however, it is just important that displaced apprenticeship graduates would not have to face worse labor market outcomes in prime age had they not experienced an elevated amount of early-career unemployment.

We address these issues of identification in more detail in the next section, which presents the results of the regression analyses. Although one can never be completely sure whether the exclusion restriction holds, we find quite robust evidence that OLS estimates of the effect of early-career unemployment on prime-age earnings are not substantially biased upwards.

\section{Regression results}

\subsection{Mean regression results}

Table 3 contains alternative specifications of the regression of cumulative prime-age earnings (in logs) on early-career unemployment. The first variant of the specification gives an estimate of the raw effect, whereas the other variants include a more or less comprehensive bunch of control variables. Note that the number of observations in the various variants of the specification differs because of imposed restrictions.

Without further controls, the raw effect of one additional day of unemployment in the early stage of professional life is estimated as $-9.69 \times 10^{-4}$. This estimate implies that a standard deviation increase in early-career unemployment (326 days) would reduce average prime-age earnings by roughly 27 percent. In contrast to the results in column (1), all further specifications include the age at graduation, the remuneration during the last year of vocational training, the number of workers and the median wage of the training firm, dummies for various occupational and industry categories, dummies for the different cohorts, and the county-specific unemployment rate prevailing in the district of the last employment spell prior to the transition from the first eight years of the early career to the prime age period. Additionally, specification (2) includes dummies for the training firms' districts. The control variables increase the adjusted coefficient of determination, adj. $R^{2}$, from 0.086 to 0.126 . The crucial parameter of early-career unemployment falls, in absolute terms, slightly (to $-9.06 \times 10^{-4}$ ). This would still imply an effect of one standard deviation of early unemployment on prime-age earnings of roughly minus 25 percent.

Specifications (3) and (4) show that the coefficient of early-career unemployment also responds only moderately if firm fixed effects are used instead of district fixed effects. Specification (4) additionally restricts the estimation sample to workers who were trained at firms with at least 50 employees and five apprentices in the year of graduation. Again, the result does not change markedly. The effect of a standard deviation of early-career unemployment on prime-age earnings is still in the order of magnitude of a 25 percent reduction.

For the same group of persons we study here, Schmillen and Umkehrer (2013) have shown that early-career unemployment leads to more unemployment later in life. Nevertheless, 60 percent of all workers are not unemployed during their prime age. Specification (5) now only considers those workers without any unemployment spells during their prime

\footnotetext{
12 The latter effect would reflect positive returns to experience or tenure respectively. However, disentangling the particular channels through which scarring actually operates is a highly challenging task, which we do not approach here. The main objective of our study is to separate any form of true state dependence between early-career unemployment and prime-age earnings from spurious correlations stemming from serially correlated unobserved heterogeneity.
} 
time. This not only excludes the effect of unobservables in the characteristics of the worker that might permanently influence the risk of unemployment, it also provides an estimate of the scarring effect of early-career unemployment on earnings net of any effects on future unemployment experience. The result indicates that the coefficient of early-career unemployment is, in absolute terms, now markedly reduced. The value of $-4.9 \times 10^{-4}$, however, remains statistically highly significant, and still implies a considerable reduction of prime-age earnings if early-career unemployment is increased by one standard deviation (about minus 14 percent). One can argue that this effect is likely an underestimation of the true effect because the imposed restriction leads to a positive selection. We will return to this point in Section 5.3.

In specification (6), finally, workers are excluded that were unemployed at the transition from the early career to the prime age period, i.e. in the eighth year after entering the labor market. This restriction controls for any persistence effects of unemployment between the two periods. As can be expected, the effect of early-career unemployment on future earnings is somewhat smaller $\left(-7.37 \times 10^{-4}\right)$ than in the baseline specifications (1) to (4), but it still implies an effect of one standard deviation of early-career unemployment of about minus 21 percent. The imposed restriction, however, not only excludes the unintended persistence effect but probably also induces a positive selection bias.

\subsection{Instrumental variable regression results}

So far we have shown that prime-age earnings are strongly correlated with early-career unemployment, and that this correlation is not weakened even if we compare only apprentices who graduated from the same training firm. As outlined in Section 4, the OLS estimates may not only reflect true scarring effects of early-career unemployment. They might also pick up spurious correlations stemming from unobserved and temporally correlated variables. Particularly, voluntary mobility would induce a downward bias, and negative selection would induce an upward bias, as long as these factors are correlated with both early-career unemployment and with prime-age earnings. To investigate and to solve this potential problem, we now instrument early-career unemployment with the event of a plant closure of the training firm, taking place in the year of graduation.

\subsubsection{Assessing exogeneity of the instrument}

Column (1) of Table 4 presents estimates of the first-stage, second-stage, and reducedform effects of a set of regressions of prime-age earnings or of early-career unemployment respectively. Only a constant is included as an additional regressor in this IV model. Hence, in the reduced form we regress prime-age earnings on a dummy variable indicating a plant closure and a constant. The result shows a difference in average earnings between displaced and non displaced workers of roughly 21 percent. The corresponding first-stage effect is the difference in the average number of days of unemployment accumulated during the early career between these two groups of workers. According to this specification, workers displaced at graduation due to plant closure experience on average almost three extra months of early-career unemployment. A first stage F-statistic well above the value of ten indicates that problems due to weak instrumentation can be ruled out, cf. Stock et al. (2002). Like the reduced-form and the first-stage effect, the resulting second-stage effect is statistically different from zero at any significance level. Yet, it appears to be unreasonably large. 
Table 3 Ordinary Least Squares Estimates of Prime-Age Earnings

\begin{tabular}{|c|c|c|c|c|c|c|}
\hline & (1) & (2) & (3) & (4) & (5) & (6) \\
\hline $\begin{array}{l}\text { Early-career } \\
\text { unempl. }\left[\times 10^{4}\right]\end{array}$ & $\begin{array}{l}-9.69 * * * \\
(0.063)\end{array}$ & $\begin{array}{l}-9.06^{* * *} \\
(0.0557)\end{array}$ & $\begin{array}{l}-8.79 * * * \\
(0.0691)\end{array}$ & $\begin{array}{l}-9.51 * * * \\
(0.108)\end{array}$ & $\begin{array}{l}-4.90 * * * \\
(0.132)\end{array}$ & $\begin{array}{l}-7.37^{* * *} \\
(0.103)\end{array}$ \\
\hline $\begin{array}{l}\text { Control variables, meas } \\
\text { Age }\end{array}$ & ured at the $t$ & $\begin{array}{l}\text { time of gradu } \\
0.0127^{* * *} \\
(0.001)\end{array}$ & $\begin{array}{l}\text { uation: } \\
0.0085^{* * *} \\
(0.0012)\end{array}$ & $\begin{array}{l}0.0138 * * * \\
(0.0016)\end{array}$ & $\begin{array}{l}0.0076^{* * *} \\
(0.0015)\end{array}$ & $\begin{array}{l}0.0072 * * * \\
(0.0012)\end{array}$ \\
\hline Remuneration & & $\begin{array}{l}0.0067^{* * *} \\
(3.35 \mathrm{e}-04)\end{array}$ & $\begin{array}{l}0.0074^{* * *} \\
(3.61 \mathrm{e}-04)\end{array}$ & $\begin{array}{l}0.0068^{* * *} \\
(4.74 \mathrm{e}-04)\end{array}$ & $\begin{array}{l}0.0032 * * * \\
(4.11 \mathrm{e}-04)\end{array}$ & $\begin{array}{l}0.0062 * * * \\
(3.63 \mathrm{e}-04)\end{array}$ \\
\hline $\begin{array}{l}\text { Size of training } \\
\text { firm }\left[\times 10^{6}\right]\end{array}$ & & $\begin{array}{l}9.29 * * * \\
(1.35)\end{array}$ & $\begin{array}{c}1.1 \\
(9.24)\end{array}$ & $\begin{array}{l}1.67 \\
(9.18)\end{array}$ & $\begin{array}{l}4.57 \\
(6.94)\end{array}$ & $\begin{array}{l}1.66 \\
(9.13)\end{array}$ \\
\hline $\begin{array}{l}\text { Median wage of } \\
\text { training firm }\end{array}$ & & $\begin{array}{l}0.0087^{* * *} \\
(0.0002)\end{array}$ & $\begin{array}{c}0.0013 \\
(0.0007)\end{array}$ & $\begin{array}{r}-0.0018 \\
(0.002)\end{array}$ & $\begin{array}{r}-0.0001 \\
(0.001)\end{array}$ & $\begin{array}{l}0.0002 \\
(0.0007)\end{array}$ \\
\hline $\begin{array}{l}\text { Unskilled manual } \\
\text { occupation }\end{array}$ & & $\begin{array}{l}0.110 * * * \\
(0.0295)\end{array}$ & $\begin{array}{l}0.101 * * \\
(0.0393)\end{array}$ & $\begin{array}{l}0.0846^{*} \\
(0.0423)\end{array}$ & $\begin{array}{l}0.202 * * * \\
(0.0575)\end{array}$ & $\begin{array}{l}0.116^{*} \\
(0.048)\end{array}$ \\
\hline $\begin{array}{l}\text { Skilled manual } \\
\text { occupation }\end{array}$ & & $\begin{array}{l}0.252 * * * \\
(0.0281)\end{array}$ & $\begin{array}{l}0.209 * * * \\
(0.0363)\end{array}$ & $\begin{array}{l}0.185^{* * *} \\
(0.0388)\end{array}$ & $\begin{array}{l}0.242 * * * \\
(0.0548)\end{array}$ & $\begin{array}{l}0.203^{* * *} \\
(0.0454)\end{array}$ \\
\hline $\begin{array}{l}\text { Technicians } \\
\text { and engineers }\end{array}$ & & $\begin{array}{l}0.330 * * * \\
(0.0293)\end{array}$ & $\begin{array}{l}0.345^{* * *} \\
(0.0377)\end{array}$ & $\begin{array}{l}0.325^{* * *} \\
(0.0402)\end{array}$ & $\begin{array}{l}0.370 * * * \\
(0.0552)\end{array}$ & $\begin{array}{l}0.335^{* * *} \\
(0.046)\end{array}$ \\
\hline $\begin{array}{l}\text { Unskilled } \\
\text { services }\end{array}$ & & $\begin{array}{l}0.0489 \\
(0.0309)\end{array}$ & $\begin{array}{c}0.0701 \\
(0.0419)\end{array}$ & $\begin{array}{c}0.0418 \\
(0.0505)\end{array}$ & $\begin{array}{l}0.181^{* *} \\
(0.0637)\end{array}$ & $\begin{array}{c}0.091 \\
(0.0512)\end{array}$ \\
\hline $\begin{array}{l}\text { Skilled } \\
\text { services }\end{array}$ & & $\begin{array}{l}0.0657^{*} \\
(0.0324)\end{array}$ & $\begin{array}{l}0.00151 \\
(0.0448)\end{array}$ & $\begin{array}{r}-0.0216 \\
(0.0489)\end{array}$ & $\begin{array}{c}0.0114 \\
(0.0624)\end{array}$ & $\begin{array}{c}-0.0235 \\
(0.0519)\end{array}$ \\
\hline $\begin{array}{l}\text { Semiprofessions } \\
\text { and professions }\end{array}$ & & $\begin{array}{l}0.451 * * * \\
(0.0326)\end{array}$ & $\begin{array}{l}0.335^{* * *} \\
(0.044)\end{array}$ & $\begin{array}{l}0.316 * * * \\
(0.0472)\end{array}$ & $\begin{array}{l}0.337^{* * *} \\
(0.0576)\end{array}$ & $\begin{array}{l}0.310^{* * *} \\
(0.0495)\end{array}$ \\
\hline $\begin{array}{l}\text { Unskilled commercial } \\
\text { occupations }\end{array}$ & & $\begin{array}{l}0.218^{* * *} \\
(0.0291)\end{array}$ & $\begin{array}{l}0.209 * * * \\
(0.041)\end{array}$ & $\begin{array}{l}0.182 * * * \\
(0.0462)\end{array}$ & $\begin{array}{l}0.248 * * * \\
(0.0598)\end{array}$ & $\begin{array}{l}0.206^{* * *} \\
(0.0492)\end{array}$ \\
\hline $\begin{array}{l}\text { Skilled commercial } \\
\text { occ. and managers }\end{array}$ & & $\begin{array}{l}0.400 * * * \\
(0.0281)\end{array}$ & $\begin{array}{l}0.340 * * * \\
(0.0366)\end{array}$ & $\begin{array}{l}0.333 * * * \\
(0.0391)\end{array}$ & $\begin{array}{l}0.363 * * * \\
(0.0545)\end{array}$ & $\begin{array}{l}0.339 * * * \\
(0.0454)\end{array}$ \\
\hline $\begin{array}{l}\text { Unemployment } \\
\text { at transition }\end{array}$ & & $\begin{array}{l}0.0327^{* * *} \\
(0.0008)\end{array}$ & $\begin{array}{l}0.0347^{* * *} \\
(0.0009)\end{array}$ & $\begin{array}{l}0.0335^{* * *} \\
(0.0013)\end{array}$ & $\begin{array}{l}0.0343^{* * *} \\
(0.0013)\end{array}$ & $\begin{array}{l}0.038^{* * *} \\
(0.001)\end{array}$ \\
\hline Constant & $\begin{array}{l}12.89 * * * \\
(0.0035)\end{array}$ & $\begin{array}{l}11.71 * * * \\
(0.0357)\end{array}$ & $\begin{array}{l}12.37 * * * \\
(0.171)\end{array}$ & $\begin{array}{l}11.44^{* * *} \\
(0.564)\end{array}$ & $\begin{array}{l}12.56^{* * *} \\
(0.153)\end{array}$ & $\begin{array}{l}12.72^{* * *} \\
(0.215)\end{array}$ \\
\hline $\begin{array}{l}\text { Observations } \\
\text { adj. } R^{2}\end{array}$ & $\begin{array}{c}728,841 \\
0.086\end{array}$ & $\begin{array}{c}728,841 \\
0.126\end{array}$ & $\begin{array}{c}728,841 \\
0.078\end{array}$ & $\begin{array}{c}293,629 \\
0.087\end{array}$ & $\begin{array}{c}432,597 \\
0.019\end{array}$ & $\begin{array}{c}612.189 \\
0.038\end{array}$ \\
\hline \multicolumn{7}{|c|}{ Further variables in regression: } \\
\hline & no & yes & yes & yes & yes & yes \\
\hline & no & yes & ye & yes & yes & yes \\
\hline & no & yes & no & no & no & no \\
\hline $\begin{array}{l}\text { Firm dummies } \\
\text { Sample restrictions: }\end{array}$ & no & no & yes & yes & yes & yes \\
\hline Train. in large firm & no & no & no & yes & no & no \\
\hline No & no & no & no & no & yes & no \\
\hline No unempl. in year 8 & no & no & no & no & no & yes \\
\hline
\end{tabular}

Notes: Standard errors clustered at the level of the training firm are in parentheses; ${ }^{*},\left({ }^{* *}\right),\left[{ }^{* *}\right]$ indicate significance at the 5, (1), [0.1] \% level; reference group for occupations: agricultural occ.; for variable definitions, see Section 2. 


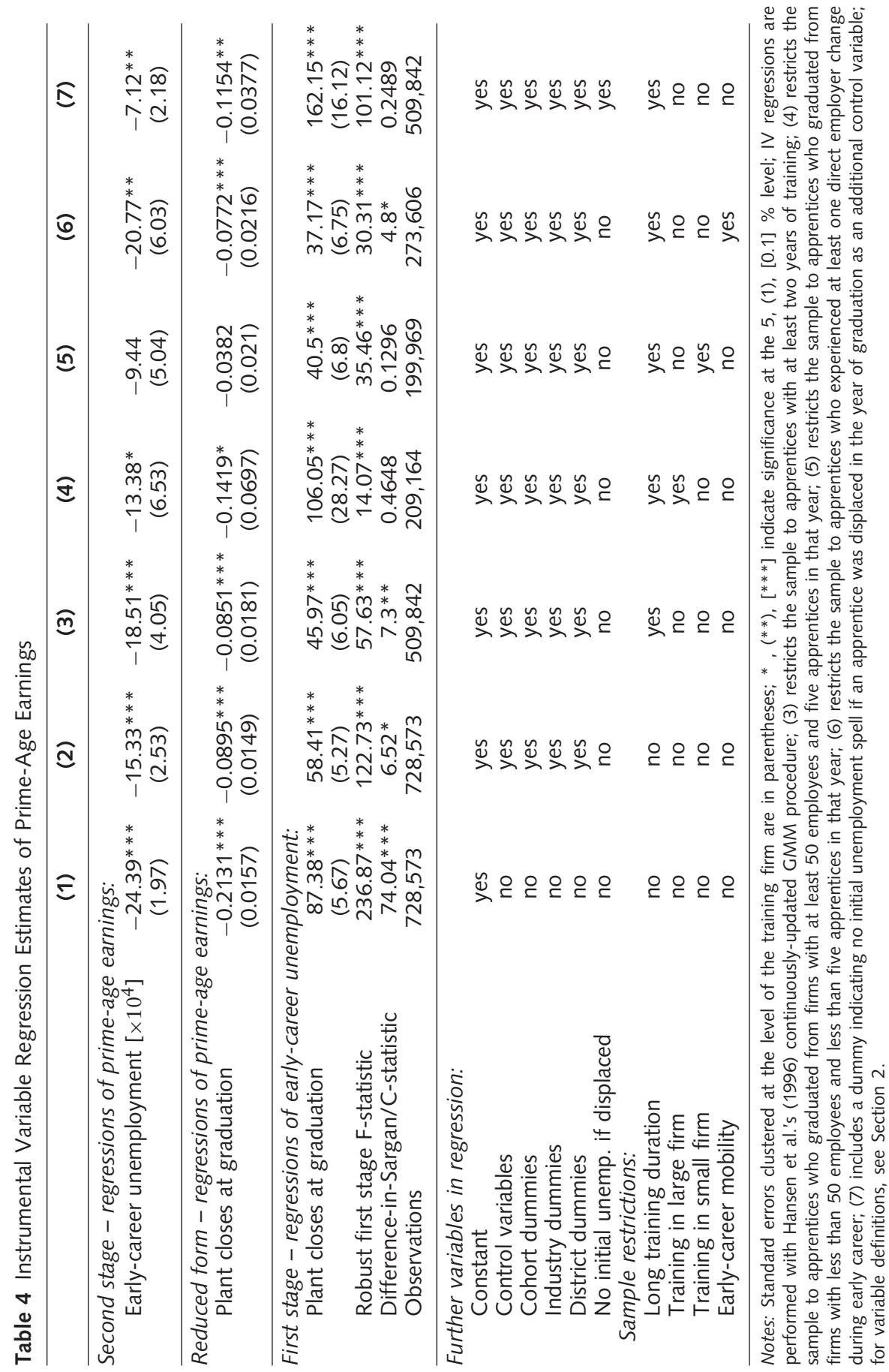


There might be systematic sorting of individuals between training firms, based on the probability that a firm closes down a few years later. When we include our control variables and fixed effects for the training firm's location to control for initial sorting in column (2), the reduced-form effect decreases to statistically still significant 9 percent, and the first-stage effect drops to about two extra months of unemployment. This pattern suggests that individuals with a below-average earning potential are trained at firms with an above-average probability to close down a few years later. Having controlled for this sorting effect, IV estimates a second-stage effect of early-career unemployment on prime-age earnings that is considerably smaller than the one presented in column (1). However, it is still statistically and economically significant.

If it was possible to correctly predict the likelihood of a plant closure, there might be further room for some strategic behavior in order to avoid starting an apprenticeship at a dying firm. To rule out this possibility, we exclude apprentices with less than two years of training in the specification displayed in column (3) of Table $4 .{ }^{13}$ While, relative to model (2) of the same table, the reduced-form effect hardly changes, the first-stage effect decreases to one and a half months, but remains statistically significant. As a result, the second-stage effect somewhat increases, and anticipation effects do not seem to induce an upward bias.

A further check of whether the instrument is as good as randomly assigned is to estimate specification (3) of Table 4 by firm size. As is shown by von Wachter and Bender (2006), wage losses caused by an early displacement tend to reflect losses of firm-size wage premia. Consequently, we should find strong reduced-form effects for apprentices who were displaced from large training firms. Apprentices who had to leave small training firms, in contrast, should show persistent reduced-form effects only if displacements were endogenous. Results from an IV model, restricted to individuals who were trained at firms with at least 50 employees and five apprentices in the year of graduation, are shown in column (4) of Table 4. Column (5) contains the same results for those apprentices who graduated from firms with less than 50 employees and less than five apprentices. For workers who were displaced from large training firms, prime-age earnings losses are on average 14 percent. This effect is significant at the 5 percent level, although only 185 individuals are treated in this group. In the latter group, 2,124 individuals are treated. These workers suffer only 3.8 percent earnings losses in prime age. The effect is no longer statistically different from zero at the 5 percent level. This result not only supports exogeneity of the instrument but also suggests that losses of firm size wage premia are an important factor behind the local scarring effect of early-career unemployment identified by IV. Of course, identification is only achieved if the exclusion restriction holds.

\subsubsection{Assessing excludability of the instrument}

The exclusion restriction might be problematic for at least three reasons: First, if exogenously displaced apprentices loose significant amounts of human capital specific to their training firm, they will suffer permanent earnings losses simply because they are no longer as productive at other firms compared to similar apprentices who had the possibility to

${ }^{13}$ Despite the absence of wage reductions, Fackler et al. (2013) report for Germany that exiting establishments somewhat shrink already more than two years before closure, relative to a matched sample of surviving establishments. Focusing on establishments that are still willing to train new apprentices two years before they close down should also mitigate this potential source of endogeneity. 
stay with their training firm. However, Gathmann and Schönberg (2010 demonstrate that human capital is highly transferable between occupations, and is rather bound to carrying out a specific task. This is particularly the case for apprenticeship training, which develops, contrary to common perceptions, general rather than firm-specific skills, cf. Winkelmann (1996); Harhoff and Kane (1997).

Correlation of plant closure at the time of graduation with persistent initial match quality, stemming from other sources than early-career unemployment, constitutes a second potential violation of the exclusion restriction. As is pointed out by Neumark (2002), the direction of this bias in the IV estimates depends on the sign of this correlation. If, for instance, displaced workers permanently accept lower-paid jobs as a direct consequence of an early layoff, IV estimates would absorb this additional effect, and would therefore be biased upwards.

As an indirect test for whether directly induced differences in initial match quality persist over more than eight years of potential experience, Neumark (2002) suggests to restrict the analysis to workers who have changed their employer during the course of the early career. The reasoning is that, if such persistent differences in initial match quality cause an upward bias in the IV estimates, this upward bias should be comparatively smaller in the sample of mobile workers. To see whether this is the case, we re-estimate specification (3) of Table 4 for the sub-sample of workers who have experienced at least one employer change with an intervening period of joblessness no longer than three weeks during the early career. Recalls are also excluded from this definition of direct employer changes. Reflecting the early career's pronounced job dynamics, almost 54 percent of workers remain in the sample. The share of mobile workers among the initially displaced is, with almost 64 percent, remarkably higher. The OLS estimate of the scarring effect in the full sample is $-8.2 \times 10^{-4}$. The corresponding IV second-stage estimate is $-18.5 \times 10^{-4}$. While a one standard deviation increase of early unemployment would reduce average prime-age earnings in the former case by roughly 23 percent, this effect almost doubles to 45 percent in the latter case. In the sample of mobile workers, the estimated coefficient of earlycareer unemployment is $-8.4 \times 10^{-4}$ for OLS, and $-20.7 \times 10^{-4}$ for IV [column (6) of Table 4]. The implied effects of one standard deviation of early unemployment on primeage earnings are about minus 24 percent and minus 49 percent respectively. Consequently, the bias implied by the difference between the IV and the OLS estimates is not smaller in the sample of mobile workers than in the full sample.

Third, almost 40 percent of apprentices who are involved in plant closures at the time of graduation are immediately reemployed, and two thirds are in covered employment within one month or less. ${ }^{14}$ If displaced but immediately reemployed workers perform similar as would have been the case in the absence of an initial plant closure, these never takers would not contribute to the IV estimate, and the exclusion restriction would not be violated. However, even without an intermediate spell of unemployment, some displaced workers might still suffer worse labor market conditions later in life if they permanently lower their reservation wage as a consequence of the take-over experience itself. Moreover, their displacement probabilities might now be higher because they do not have insider status and could not be screened during training.

${ }^{14}$ For those 9 percent of apprentices who stay the longest time without employment after displacement, in contrast, it takes at least one year to find new employment. 
To explore potential bias arising from immediate take-overs, we include a dummy variable indicating the absence of an initial period of unemployment if the apprentice was displaced from his training firm into specification (3) of Table 4. The results are displayed in column (7) of Table 4. The difference in average prime-age earnings between the displaced and the non-displaced is now around 11 percent. Displaced workers are on average more than five months longer unemployed during the early career. The IV second-stage estimate of early-career unemployment drops to $-7.1 \times 10^{-4}$, which is even smaller in magnitude than the corresponding OLS estimate of $-8.2 \times 10^{-4}$ (not reported in the table). The implied effect of a one standard deviation increase of early-career unemployment on the mean of prime-age earnings is minus 20.7 percent, which is still substantial. Note, however, that unemployment at a later point in the early career could also be a delayed reaction to an initial plant closure. If this delayed unemployment experience in turn results in future earnings loss, it is part of the scarring effect, and the exclusion restriction would not be violated. Explicitly controlling for direct take-over therefore could also switch off some of the channels through which scarring actually operates. In any case, even if the exclusion restriction was violated, the associated bias does not appear to be large enough to explain the finding of economically significant scarring effects of early-career unemployment on prime-age earnings.

\subsubsection{Interpreting the instrumental variable regression results}

IV produces point estimates of the scarring effect of early-career unemployment that are usually larger than the corresponding OLS estimates. Three mechanisms could explain this finding: First, if plant closure of the training firm is a valid instrument for early-career unemployment, larger IV estimates imply downward biased OLS estimates. As outlined above, such a downward bias arises if, for instance, early job shopping activities involve temporary periods of unemployment but improve labor market outcomes in the future, cf. Neumark (2002). An alternative explanation could be the presence of attenuation bias induced by classical measurement error in early-career unemployment.

Second, in the case of heterogenous scarring effects, IV estimates a treatment effect for the subpopulation of compliers, i.e. an effect for those workers who experienced an elevated amount of early-career unemployment only because their training firm had to close down. In our application, it appears reasonable to assume that less skilled workers with lower reemployment probabilities are overrepresented among the group of compliers. As we will show in the next section, scarring effects substantially decrease across the distribution of prime-age earnings. It is therefore not surprising that a local average scarring effect estimated by IV exceeds the corresponding OLS estimate. ${ }^{15}$

Third, given the results presented above, we are quite confident that the instrument is as good as randomly assigned once sorting between training firms is taken into account. Although we find no evidence that violations of the exclusion restriction invalidate the finding of significant and long-lasting scarring effects, we can never be completely sure that IV estimates are not biased upwards. Note, however, that the IV estimates are quite imprecise and that the null of exogeneity of early-career unemployment cannot be rejected

\footnotetext{
${ }^{15}$ Appendix 8.4 of Schmillen and Umkehrer (2013) provides further evidence that scarring effects are not the same for everybody. In the presence of heterogenous scarring effects, however, the IV estimates presented in this paper may be interpreted as upper bounds for the average treatment effect on the treated.
} 
at the 1 percent significance level in the majority of cases. ${ }^{16}$ If early-career unemployment is in fact exogenous in a regression of prime-age earnings, however, OLS estimates are not only consistent but also efficient. We therefore treat early-career unemployment as exogenous throughout the remaining part of this paper.

\subsection{Scarring effect heterogeneity across the earnings distribution}

Workers who do generally well in the labor market might react very differently to early unemployment experiences compared to workers who perform rather poorly. To explore this possibility, we now investigate whether the scarring effect of early-career unemployment varies across the unconditional distribution of prime-age earnings. For this purpose, we run regressions of the recentered influence function (RIF) of each unconditional decile of cumulative prime-age earnings, see Firpo et al. (2009). The models' specification is identical to the one in column (2) of Table 3. However, a coefficient estimated using RIF regression can be interpreted as the partial effect that a regressor has on the specified unconditional quantile of the prime-age earnings distribution.

The estimated effects of early-career unemployment on each decile of prime-age earnings are presented in the upper panel of Table 5. Early-career unemployment has a significant negative effect on each decile. These effects are substantially larger at the lower than at the upper tail: At the first decile, an increase of early-career unemployment by one standard deviation (326 days) reduces prime-age earnings by 56 percent. The corresponding scarring effect on the median is 11 percent, and at the ninth decile it is roughly 7 percent. ${ }^{17}$ We further restrict the quantile regression analysis to the 60 percent of workers who managed to completely avoid unemployment during their prime age period. This positive selection probably induces a downward bias. The true scarring effects of early-career unemployment on earnings, net of its effects on unemployment, should therefore be bounded by the effects for the full sample (first panel of Table 5), and for the selected sample (second panel of Table 5). At the bottom of the prime-age earnings distribution, earnings losses from unemployment experienced early in professional life are still substantial, even if exposure to unemployment during prime age is avoided. But the effects decrease rapidly as we move up the earnings distribution: An increase of early-career unemployment by one standard deviation (in the full sample) reduces the first decile of prime-age earnings for this selected group of workers by 45 percent, the median by 4.5 percent, and the ninth decile by 3.1 percent. Consequently, workers with a low earning potential, but without any prime-age unemployment, still suffer substantial earnings losses from early-career unemployment. On the contrary, workers with a high earning potential, and who avoid repeated exposure to unemployment, manage to almost completely offset these negative scarring effects.

${ }^{16}$ Neither a potential downward bias in OLS estimates, nor the sum of a complier effect and a potential upward bias in IV estimates appear to be - in absolute terms - large enough to lead to a rejection of the null in these cases.

17 The corresponding effects on the conditional distribution of prime-age earnings are similar in magnitude, and also decrease across this distribution. They are presented in Table A3 in the Appendix. Decreasing scarring effects within training firms, training occupations, and industry sectors provide some evidence that the revealed pattern is the result of a fundamental segmentation of the labor market rather than of a persistent demand shock hitting firms, occupations, and industries in different ways. 


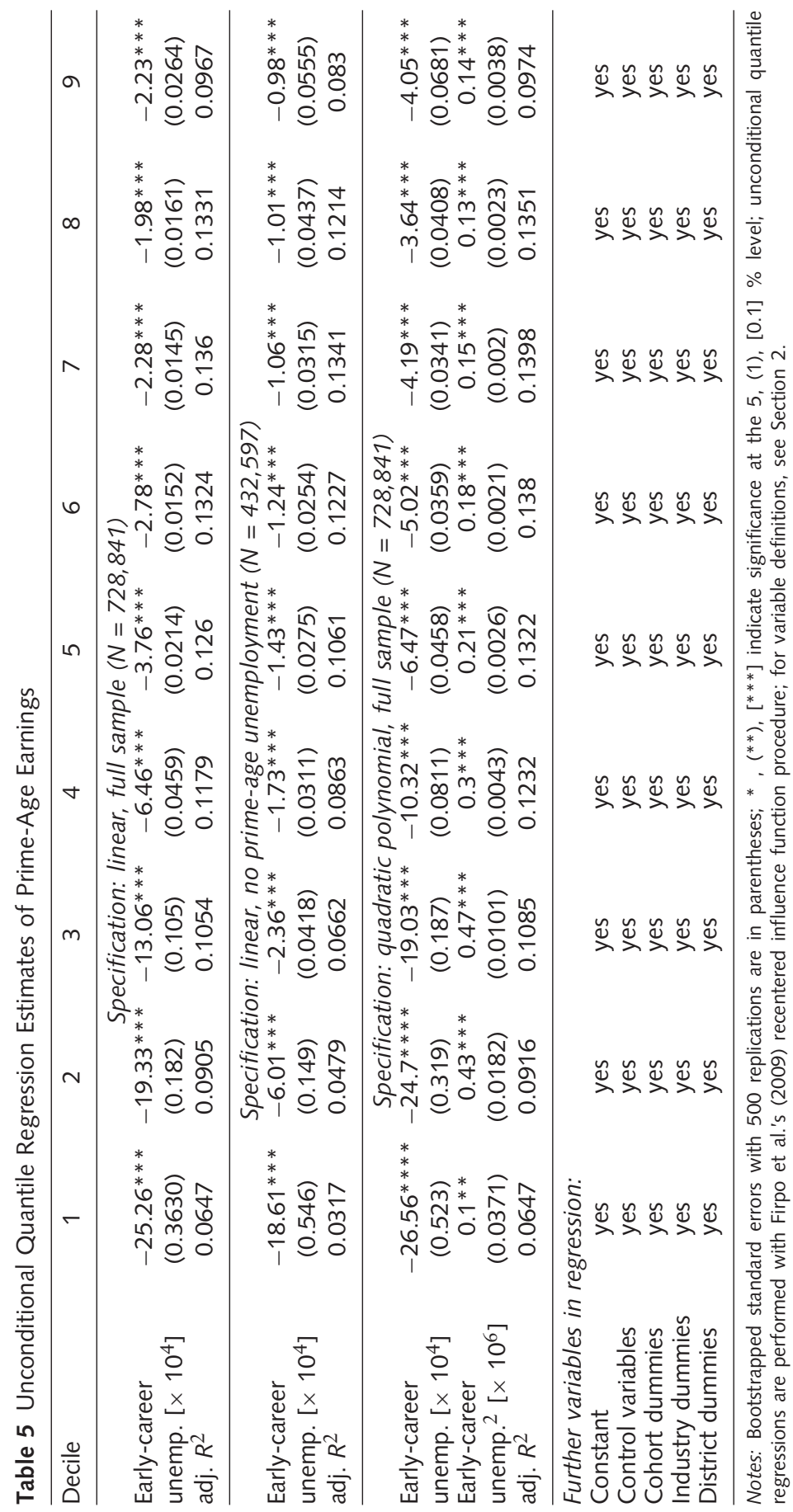




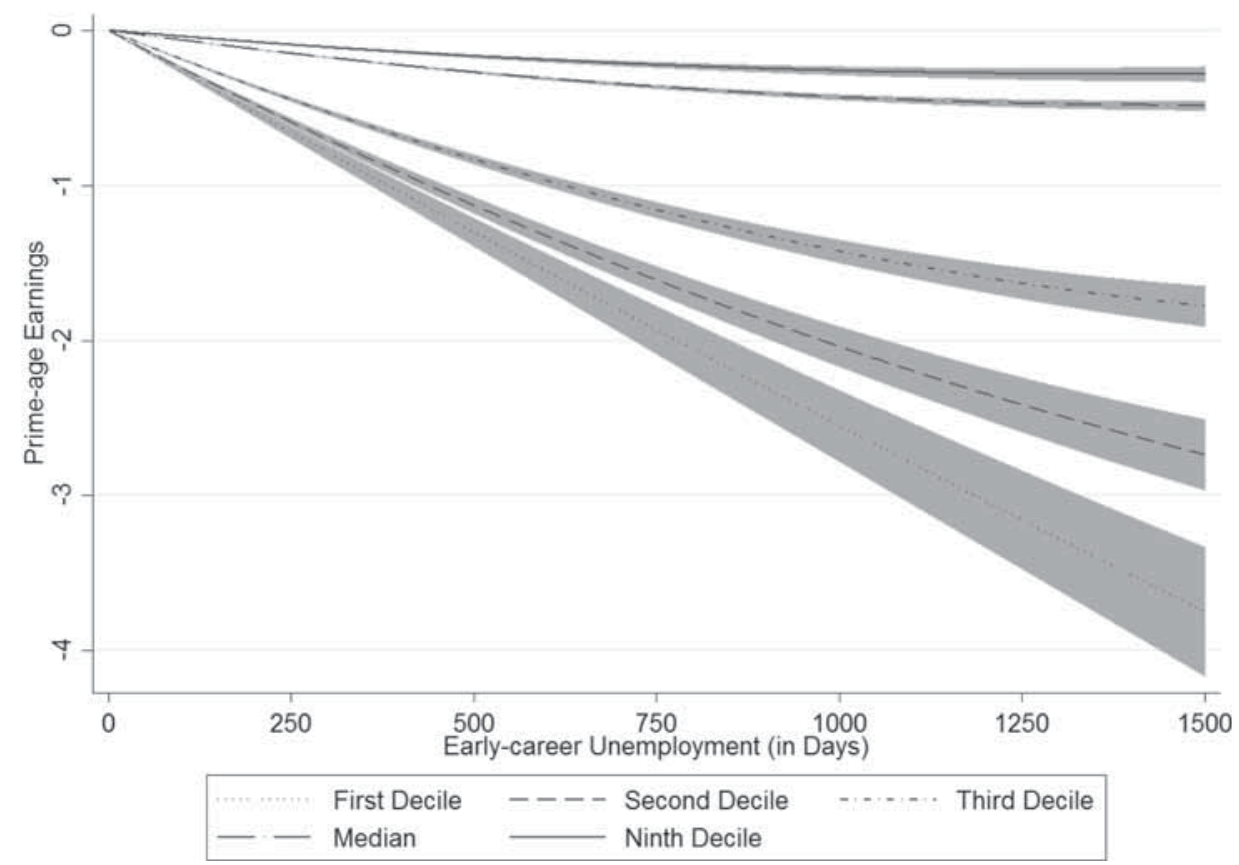

Figure 3 Prime-Age Earnings and Early-Career Unemployment Profiles by Earnings Decile

Notes: Earnings-unemployment profiles by decile of prime-age earnings based on coefficients estimated by unconditional quantile regressions; unconditional quantile regressions are performed with Firpo et al.'s (2009) recentered influence function procedure; model specifications are similar to column (2) of Table 3, but additionally include early-career unemployment squared; the coefficients on the control variables are set to zero; for variable definitions, see Section 2.

In the final step of our quantile regression analysis, we return to the full sample of workers, but additionally include early-career unemployment squared in the RIF regressions of prime-age earnings. We therefore allow the scarring effect not only to vary across the unconditional distribution of prime-age earnings, but also by the duration of earlycareer unemployment. The estimated coefficients on our key regressor are displayed in the third panel of Table 5. The emerging earnings-unemployment profiles, with all other coefficients of the model set to zero, are depicted for selected deciles in Figure 3. The scarring effects seem to be almost linear in the duration of early-career unemployment at the tails of the prime-age earnings distribution. In the middle of this distribution, they are even slightly convex. We conclude from these patterns that the linearity assumption imposed so far provides a sufficient approximation for modeling the conditional mean or unconditional quantile functions of prime-age earnings respectively. 


\section{Conclusions}

We analyzed administrative linked employer-employee data on more than 720,000 German males who graduated from Germany's dual apprenticeship system during the years 1978,1979 , and 1980, to see whether unemployment experienced early in professional life permanently reduces earnings accumulated during prime age.

OLS estimates, controlling for training firm fixed effects and for other initial conditions, suggest that an increase of unemployment within the first eight years since labor market entry by one standard deviation (326 days) reduces average earnings in the following 16 years by almost 25 percent, other things being equal. For the 60 percent of workers who avoided exposure to unemployment during their prime age period, this earnings loss drops to 14 percent, which is still substantial.

Yet, beyond large earnings losses on average, we also observe that workers who perform generally well in the labor market manage to overcome the adverse effects of early-career unemployment to a large extent. This is particularly the case if they avoid further exposure to unemployment. Other workers, in contrast, suffer substantial earnings losses, even if the analysis is restricted to those workers who experience no unemployment during their prime age period.

We applied an instrumental variable strategy based on plant closure of the firm where the apprentice was trained, taking place in the year of his graduation. This approach yields estimates of the scarring effect that are, albeit generally larger in magnitude, not statistically different from the corresponding OLS estimates. We thoroughly discussed and investigated the assumptions under which this strategy identifies a local average treatment effect on the treated, and found no evidence that potential violations could explain the finding of economically significant and long-lasting scarring effects.

The overall evidence suggests that the duration of early-career unemployment can be treated as exogenous in our regressions of prime-age earnings. One explanation for this finding is that we focus on a quite homogenous group of workers. These workers face a severe recession as a consequence of the second oil price shock early in professional life, which is probably the main driving force behind most early unemployment experiences. Consistent with our view, Franz (1981) shows that demand side factors are the major determinant of youth unemployment durations in Germany, while individual characteristics are only of minor importance.

A policy that aims at preventing the emergence of youth unemployment, or at least reduces its duration, is highly supported because our results indicate that substantial income losses in the subsequent professional life would be avoided. This is particularly the case for workers with a low earning potential. A policy initiative against youth unemployment is therefore not only a measure for increasing prime-age earnings on average, it would also tend to reduce the inequality in the income distribution. 


\section{Appendix}

Table A1 Summary Statistics

\begin{tabular}{|c|c|c|c|c|c|}
\hline & $N$ & mean & $\begin{array}{l}\text { standard } \\
\text { deviation }\end{array}$ & minimum & maximum \\
\hline Prime-age earnings (in logs) & 728,841 & 12.7 & 1.1 & 2.6 & 14.7 \\
\hline Early-career unemployment & 728,841 & 184.7 & 325.9 & 0 & 2,886 \\
\hline Plant closure at graduation & 728,573 & 0.008 & - & 0 & 1 \\
\hline Class of 1979 & 728,841 & 0.336 & - & 0 & 1 \\
\hline Class of 1980 & 728,841 & 0.350 & - & 0 & 1 \\
\hline Age at graduation & 728,841 & 18.7 & 1.7 & 15 & 26 \\
\hline Remuneration at graduation & 728,841 & 10.9 & 5.8 & 0.01 & 176.6 \\
\hline Training occupation & \multicolumn{5}{|c|}{ reference: agricultural occ. } \\
\hline unskilled manual occ. & 728,841 & 0.079 & - & 0 & 1 \\
\hline skilled manual occ. & 728,841 & 0.668 & - & 0 & 1 \\
\hline technicians and engineers & 728,841 & 0.035 & - & 0 & 1 \\
\hline unskilled services & 728,841 & 0.016 & - & 0 & 1 \\
\hline skilled services & 728,841 & 0.013 & - & 0 & 1 \\
\hline semiprofessions and professions & 728,841 & 0.016 & - & 0 & 1 \\
\hline unskilled commercial occ. & 728,841 & 0.027 & - & 0 & 1 \\
\hline skilled commercial occ. and managers & 728,841 & 0.128 & - & 0 & 1 \\
\hline Size of training firm & 728,841 & 987.2 & 4,491 & 1 & 57,236 \\
\hline Median wage of training firm & 728,841 & 38.1 & 9.0 & 1.2 & 78.4 \\
\hline Sector of training firm & \multicolumn{5}{|c|}{ reference: agriculture } \\
\hline energy and mining & 728,841 & 0.025 & - & 0 & 1 \\
\hline manufacturing & 728,841 & 0.498 & - & 0 & 1 \\
\hline construction & 728,841 & 0.176 & - & 0 & 1 \\
\hline trade & 728,841 & 0.135 & - & 0 & 1 \\
\hline transport and communications & 728,841 & 0.033 & - & 0 & 1 \\
\hline financial intermediation & 728,841 & 0.023 & - & 0 & 1 \\
\hline other services & 728,841 & 0.077 & - & 0 & 1 \\
\hline non-profits and households & 728,841 & 0.003 & - & 0 & 1 \\
\hline public administration & 728,841 & 0.018 & - & 0 & 1 \\
\hline Local unemployment rate at transition & 728,841 & 9.0 & 3.5 & 0.9 & 19.8 \\
\hline
\end{tabular}

Notes: Own calculations with IEB data. 
Table A2 Selected Moments of the Distributions of Early-Career Unemployment and Prime-Age Earnings

\begin{tabular}{lcc}
\hline & Early-career unemployment (in days) & Prime-age earnings (in 2005 Euro) \\
\hline mean & 185 & 461,360 \\
standard deviation & 326 & 274,190 \\
minimum & 0 & 13,33 \\
maximum & 2,886 & $2,350,436$ \\
percentile & & \\
5 & 0 & quantile \\
10 & 0 & 34,383 \\
15 & 0 & 81,893 \\
20 & 0 & 137,602 \\
25 & 0 & 198,119 \\
30 & 0 & 260,760 \\
35 & 0 & 321,533 \\
40 & 0 & 374,745 \\
45 & 0 & 415,297 \\
50 & 15 & 446,503 \\
55 & 43 & 472,192 \\
60 & 77 & 495,860 \\
65 & 119 & 519,371 \\
70 & 172 & 544,117 \\
75 & 242 & 571,554 \\
80 & 326 & 603,838 \\
85 & 431 & 644,116 \\
90 & 603 & 700,393 \\
95 & 873 & 801,721 \\
& & 977,323
\end{tabular}

Notes: Own calculations with IEB data; number of observations: $728,841$. 


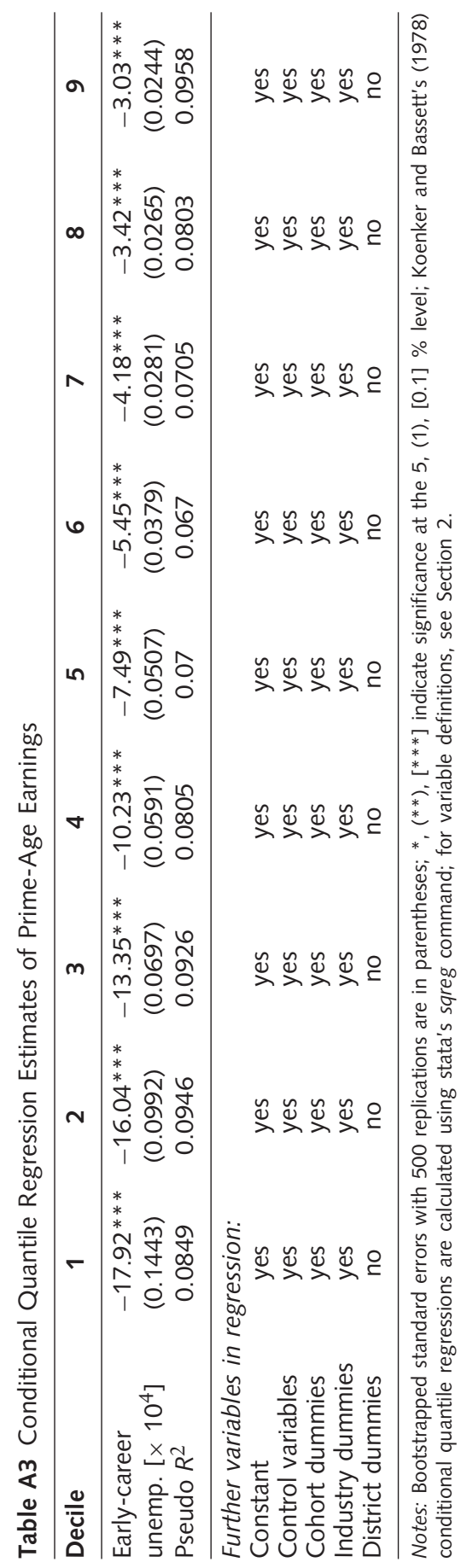




\section{References}

Adda, J., C. Dustmann, C. Meghir, J. Robin (2013), Career Progression, Economic Downturns, and Skills. Mimeo.

Arulampalam, W., A. Booth, M. Taylor (2000), Unemployment Persistence. Oxford Economic Papers 52: 24-50.

Arulampalam, W. (2001), Is Unemployment Really Scarring? Effects of Unemployment Experiences on Wages. The Economic Journal 111: 585-606.

Biewen, M., S. Steffes (2010), Unemployment persistence: Is there evidence for stigma effects? Economics Letters 106: 188-190.

Blanchower, D.G, A.J. Oswald (1994), The Wage Curve. MIT Press, Cambridge, MA.

Corcoran M., M. Hill (1985), Reoccurrence of Unemployment among Adult Men. The Journal of Human Resources 20: 165-183.

Deutsche Bundesbank (2012), http://www.bundesbank.de; Time series BBK01.UJFB99:

Consumer price index. Retrieved in February 2012, Deutsche Bundesbank, Frankfurt a.M.

Dustmann, C., C. Meghir (2005), Wages, Experience and Seniority. Review of Economic Studies 72: 77-108.

Ellwood, D. (1982), Teenage Unemployment: Permanent Scars or Temporary Blemishes. Pp. 349-390 in: R. Freeman, D. Wise (eds.), The Youth Labor Market Problem: Its Nature, Causes, and Consequences. NBER Books, Cambridge.

Fackler, D., C. Schnabel, J. Wagner (2013), Lingering illness or sudden death? Pre-exit employment developments in German establishments. Industrial and Corporate Change: 1-20.

Farber, H.S (1993), The Incidence and Cost of Job Loss: 1982-1991. Brookings Papers on Economic Activity: Microeconomics: 73-132.

Firpo, S., N.M. Fortin, T. Lemieux (2009), Unconditional Quantile Regressions. Econometrica 77: 953-973.

Franz, W. (1981), Zur Dauer der Jugendarbeitslosigkeit: Theoretische Überlegungen, empirische Resultate und wirtschaftspolitische Implikationen. Mitteilungen aus der Arbeitsmarkt- und Berufsforschung 14.

Franz, W., J. Inkmann, W. Pohlmeier, V. Zimmermann (1997), Young and out in Germany: On the Youths' chances of Labor Market Entrance in Germany. NBER Working Paper 6212.

Franz, W., V. Zimmermann (2002), The transition from apprenticeship training to work. International Journal of Manpower 23: 411-425.

Gathmann, C., U. Schönberg (2010), How General is Human Capital? A Task-Based Approach. Journal of Labor Economics 28: 1-49.

Gibbons, R., L. Katz (1991), Layoffs and Lemons. Journal of Labor Economics 9: 351-380.

Gregg, P. (2001), The Impact of Youth Unemployment on Adult Unemployment in the NCDS. Economic Journal 109: 626-653.

Gregg, P., E. Tominey (2005), The Wage Scar from Male Youth Unemployment. Labour Economics 12: 487-509.

Hamermesh, D. (1987), The Costs of Worker Displacement. Quarterly Journal of Economics 102: 51-75.

Hansen, L.P, J. Heaton, A. Yaron (1996), Finite-Sample Properties of Some Alternative GMM Estimators. Journal of Business \& Economic Statistics 14: 262-280.

Harhoff, D., T.J. Kane (1997), Is the German apprenticeship system a panacea for the U.S. labor market? Journal of Population Economics 10: 171-196.

Heckman, J., G. Borjas (1980), Does Unemployment Cause Future Unemployment? Definitions, Questions and Answers from a Continuous Time Model of Heterogeneity and State Dependence. Economica 47: 247-283.

Hethey, T., J. Schmieder (2010), Using Worker Flows in the Analysis of Establishment Turnover - Evidence from German Administrative Data. FDZ Datenreport 06/2010.

Hethey-Maier, T., S. Seth (2010), The Establishment History Panel (BHP) 1975-2008 - Handbook Version 1.0.2. FDZ Datenreport 04/2010. 
Hippach-Schneider, U., M. Krause, C. Woll (2007), Vocational Education and Training in Germany: Short Description. European Centre for the Development of Vocational Training, Thessaloniki.

Koenker, R., G. Bassett (1978), Regression Quantiles. Econometrica 46: 33-50.

Möller, J. (2010), The German labor market response in the world recession - De-mystifying a miracle. Journal for Labour Market Research 42: 325-336.

Mroz, T., T. Savage (2006), The Long-Term Effects of Youth Unemployment. Journal of Human Resources 41: 259-293.

Mühleisen, M., K.F. Zimmermann (1994), New Patterns of Labour Mobility: A Panel Analysis of Job Changes and Unemployment. European Economic Review 38: 793-801.

Neumark, D. (2002), Youth Labor Markets In The United States: Shopping Around Vs. Staying Put. The Review of Economics and Statistics 84: 462-482.

Niedergesäss, M. (2012), Duration Dependence, Lagged Duration Dependence, and Occurrence Dependence in Individual Employment Histories. University of TübingenWorking Papers in Economics and Finance 26.

Nilsen, Ø., K. Holm (2011), Scarring Effects of Unemployment. CESifo Working Paper 3675.

Nordström Skans, O. (2011), Scarring Effects of the First Labor Market Experience. IZA Discussion Paper 5565.

Oberschachtsiek, D., P. Scioch, C. Seysen, J. Heining (2009), Integrated Employment Biographies Sample IEBS: Handbook for the IEBS in the 2008 Version. FDZ Datenreport 03/2009.

OECD (2014), Labor Force Statistics by Sex and Age. Retrieved in February 2014, OECD, Paris.

Ruhm, C.J. (1991), Are Workers Permanently Scarred by Job Displacements? The American Economic Review 81: 319-324.

Ryan, P. (2001), The School-to-Work Transition: A Cross-National Perspective. Journal of Economic Literature 39: 34-92.

Schmillen, A., M. Umkehrer (2013), The Scars of Youth - Effects of Early-Career Unemployment on Future Unemployment Experience. IAB Discussion Paper 06/2013.

Spence, M. (1973), Job Market Signaling. The Quarterly Journal of Economics 87: 355-374.

Stock, J., J. Wright, M. Yogo (2002), A Survey of Weak Instruments and Weak Identification in Generalized Method of Moments. Journal of Business \& Economic Statistics 20: 518-529.

Topel, R., M. Ward (1992), Job Mobility and the Careers of Young Men. The Quarterly Journal of Economics 107: 439-479.

Von Wachter, T., S. Bender (2006), In the Right Place at theWrong Time: The Role of Firms and Luck in Young Workers' Careers. The American Economic Review 96: 1679-1705.

Winkelmann, R. (1996), Employment Prospects and Skill Acquisition of ApprenticeshipTrained Workers in Germany. Industrial and Labor Relations Review 49: 658-672.

Univ.-Prof. Dr. rer. soc. Dr. h.c. Joachim Möller, Institute for Employment Research (IAB), Regensburger Strasse 104, 90478 Nuremberg, Germany, University of Regensburg, Universitätsstrasse 31, 93053 Regensburg, Germany, and Institute for the Study of Labor, Schaumburg-Lippe-Strasse 5-9, 53113 Bonn, Germany.

joachim.moeller@iab.de

Matthias Umkehrer, Institute for Employment Research (IAB), Regensburger Strasse 104, 90478 Nuremberg, Germany.

matthias.umkehrer@iab.de 